\title{
Peroxidase activity and initial growth of 'Barbosa' peach on clonal rootstocks
}

\author{
Chirlene Márcia Oldoni ${ }^{1}$, Alexandre Augusto Nienow ${ }^{2}$, \\ Jurema Schons ${ }^{3}$, Newton Alex Mayer ${ }^{4}$
}

\begin{abstract}
In the peach nursery trees production, the use of rootstocks with unknown genetic identity obtained from peach seeds in the canning industry is frequent. The hypothesis tested was that there are rootstocks that express greater graft compatibility, enabling greater survival and growth, and that peroxidase activity can be used as indication of graft incompatibility. The aim of this study was to evaluate the survival and the peroxidase activity efficiency in identifying graft incompatibility and the trunk diameter growth of 'Barbosa' peach grafted onto 18 Prunus clonal rootstocks, propagated by herbaceous cuttings, compared to own-rooted scion trees. The experimental design was three randomized blocks, with one tree per plot. The first three vegetative cycles of trees conducted in double Y $(5.0 \mathrm{~m} \times 2.0 \mathrm{~m})$ without irrigation were evaluated. The highest trunk diameter growth was provided by 'Okinawa', 'Tsukuba-1', 'Tsukuba-2', Mexico F1 and 'Flordaguard' rootstocks, without differing from own-rooted 'Barbosa' peach. Peroxidase activity differs by rootstock effect at the beginning of the dormancy period, and is higher than in vegetative growth, especially in interspecific graft combinations. Peroxidase activity is a biochemical indicator of stress, but should not be used alone and generalized to characterize graft incompatibility.
\end{abstract}

Index terms: Prunus persica (L.) Batsch., graft, graft compatibility.

\section{Atividade de peroxidase e crescimento inicial do pessegueiro 'Barbosa' sobre porta-enxertos clonais}

Corresponding author: chirlenemo@gmail.com

Received: May 10, 2019 Accepted: October 10, 2019

Copyright: All the contents of this journal, except where otherwise noted, is licensed under a Creative Commons Attribution License.

\section{(cc) $\mathbf{E Y}$}

\begin{abstract}
Resumo - Na produção de mudas de pessegueiro é frequente o uso de porta-enxertos de identidade genética desconhecida, obtidos a partir de caroços nas indústrias de conservas. A hipótese testada foi de que existem porta-enxertos que expressam maior compatibilidade, possibilitando maior sobrevivência e melhor crescimento, e que a atividade da peroxidase pode ser empregada como indicativo de incompatibilidade. O objetivo do trabalho foi avaliar a sobrevivência, a eficiência da atividade da peroxidase em identificar incompatibilidades e o crescimento do diâmetro do tronco do pessegueiro 'Barbosa' enxertado sobre 18 porta-enxertos clonais do gênero Prunus, propagados por estaquia herbácea, comparados com a copa autoenraizada. O delineamento foi em três blocos casualizados, com uma planta por parcela. Foram avaliados os três primeiros ciclos vegetativos de plantas conduzidas em "Y duplo" (5,0m x 2,0m), sem irrigação. O maior crescimento em diâmetro de tronco foi proporcionado pelos porta-enxertos 'Okinawa', 'Tsukuba-1', 'Tsukuba-2', México F1 e 'Flordaguard', sem diferir de 'Barbosa' autoenraizado. A atividade da peroxidase difere por efeito dos porta-enxertos no início do período de dormência, e é mais elevada que no crescimento vegetativo, principalmente em combinações interespecíficas de enxertia. A atividade da peroxidase é um indicador bioquímico de estresse, mas não deve ser utilizada sozinha e generalizada para a caracterização da incompatibilidade de enxertia.
\end{abstract}

Termos para indexação: Prunus persica (L.) Batsch., enxertia, compatibilidade de enxertia.

\footnotetext{
${ }^{1}$ Doctor in Agronomy, Graduate Program in Agronomy (PPGAgro), University of Passo Fundo (UPF), Erechim-RS, Brazil. Email: chirlenemo@ gmail.com ${ }^{(\text {ORCID 0000-0003-3607-985X) }}$

${ }^{2}$ Professor at the Faculty of Agronomy and Veterinary Medicine (FAMV) and PPGAgro / UPF. Passo Fundo-RS, Brazil. Email: alexandre@ upf.br (ORCID 0000-0003-0423-3613)

${ }^{3}$ Professor at the Institute of Biological Sciences (ICB) and PPGAgro / UPF. Passo Fundo-RS, Brazil. Email: schons@ upf.br $^{(\mathrm{ORCID} 0000-0002-5923-7032)}$ ${ }^{4}$ Researcher at Embrapa Clima Temperado, Pelotas-RS, Brazil. Email: alex.mayer@embrapa.br(ORCID 0000-0001-6689-8202)
} 


\section{Introduction}

Woody fruit species of temperate climate are predominantly propagated by grafting onto rootstocks with characteristics of interest, allowing expanding cultivation to regions with different climate and soil conditions and to solve agronomic problems.

In southern Brazil, 'Aldrighi' and 'Capdeboscq' peach cultivars, widely cultivated for canning, have been used in the production of rootstocks due to the ease of obtaining seeds and reasonable germination percentage. However, they were not selected for rootstock purposes (PEREIRA; MAYER, 2005). With the reduction of the planting area of these cultivars and substitution for others, the varietal mixture in the production of rootstocks became more accentuated, keeping the habit of obtaining seeds from canning industries.

The unknown genetic identity prevents knowing whether the material used is resistant to nematodes. The early death of peach trees is another serious problem (MAYER; UENO, 2012), which being considered a physiological disorder, it is suspected that the rootstock may be related to the death causes.

The union between graft and rootstock initially involves callus formation among cambial regions, which may occur in both compatible and incompatible combinations. Subsequently, callus parenchyma cells differentiate into cambial cells, which merge and phloem and xylem reconstitution occur, connecting the vascular system, considered the decisive phenomenon for the grafting success (PINA; ERREA, 2005; HARTMANN et al., 2011; PINA et al., 2012).

The likelihood of rootstock-scion graft compatibility is reduced as the combination comprises taxonomically closer plants. Combinations between different species may be viable and bring agronomic benefits, but genetically different individuals may be incompatible (TELLES et al., 2009; HARTMANN et al., 2011; PINA et al., 2012). Graft incompatibility involves anatomical, physiological, biochemical and molecular interactions between plants, considered extremely complex and difficult to evaluate and understand (PEREIRA et al., 2014).

Graft incompatibility symptoms in woody species include bark thickening in the connection region, chlorotic leaves, premature leaf fall, budding delay, vigor differences between rootstock and scion, excessive stem thickening below, above or at the point of graft union, graft union disruption, reduced vegetative growth, low productivity and premature plant death (USENIK et al., 2006; HARTMANN et al., 2011; ZARROUK et al., 2010).

Studies have been conducted to understand the involvement of peroxidase activity and phenolic compounds in graft compatibility, and participation in tissue lignification (PASSARDI et al., 2005; ZARROUK et al., 2010; LIU, 2012; PEREIRA et al. , 2013;
FERNÁNDEZ-PÉREZ et al., 2015; BARON et al., 2018), important in the early stages of connection between graft and rootstock (PINA; ERREA, 2005; HARTMANN et al., 2011), because cell walls are dynamic structures composed of polysaccharides, proteins, minerals, and phenolic compounds such as lignin (HERRERO et al., 2014).

Peroxidases have many molecular forms, participating in different biochemical reactions, acting in lignification, ethylene biosynthesis and auxin degradation (PASSARDI et al., 2005). The quantification of the enzyme activity in plant tissues may be an early indication of the graft compatibility in Prunus species and cultivars (TELLES et al., 2009).

Knowledge of the rootstock agronomic characteristics and interaction with the scion is of utmost importance for appropriate choice. The hypothesis of this research was that there are Prunus rootstocks that express greater graft compatibility, enabling greater survival and peach growth, and that peroxidase activity may be indicative of the best combinations. The aim of this study was therefore to evaluate the survival and peroxidase activity efficiency in identifying graft incompatibility and the trunk diameter growth of 'Barbosa' peach trees grafted onto 18 Prunus clonal rootstocks.

\section{Material and methods}

The research was conducted at an Observation Unit located at the Center for Extension and Agronomic Research (Cepagro), Faculty of Agronomy and Veterinary Medicine (FAMV) - University of Passo Fundo (UPF), Rio Grande do Sul State (28 $41^{\prime}$ 'S, and $52^{\circ} 45^{\prime} \mathrm{W}, 709 \mathrm{~m}$ a.s.1.), Brazil. The soil belongs to the Passo Fundo mapping unit, characterized as a typical dystrophic Red Latosol. Normal temperatures in Passo Fundo (1961-1990) are: annual average of $17.7^{\circ} \mathrm{C}$; average maximum $23.6^{\circ} \mathrm{C}$; and average minimum of $13.2^{\circ} \mathrm{C}$. Average annual precipitation is $1,800 \mathrm{~mm}$. In the fall / winter of 2015, 2016 and 2017, chill hours accumulation $(\mathrm{CH})$ from May to August was, respectively, 72.6, 369.4 and $131.8 \mathrm{HF} \leq 7,0^{\circ} \mathrm{C}$, and of 349.7, 759.6 and 392.2 $\mathrm{HF} \leq 10^{\circ} \mathrm{C}$ (EMBRAPA, 2017).

The experiment consisted of evaluating tree survival, peroxidase activity in bark and leaves, and trunk diameter growth (rootstock and scion) of 'Barbosa' peach [Prunus persica (L.) Batsch.] grafted onto 18 Prunus rootstocks compared to own-rooted scion trees (control without rootstock). Seven peach rootstock cultivars or rootstock selection were tested: 'Capdeboscq', I-6752-4, Mexico F1, 'Okinawa', 'Tsukuba-1', 'Tsukuba-2' and 'Tsukuba-3'; two plum cultivars (P. salicina Lindl.): 'Genovesa' and 'Santa Rosa'; two japanese apricot trees (P. mume Sieb. \& Zucc.): selection Clone 15 and 'Rigitano'; P. cerasifera Ehrh.: 'Mirabolano 29C'; and six interspecific hybrids: 'Barrier' and 'Cadaman' $[P$. 
persica $\mathrm{x} P$. davidiana (Carr.) Franch.], 'Flordaguard' ('Chico 11' x P. davidiana), G x N.9 [P. persica $\times$ P. dulcis (Mill.) From Weeb.], 'Ishtara' [(P. cerasifera $\mathrm{x}$ P. salicina) $\mathrm{x}(P$. cerasifera x $P$. persica)] and 'Marianna 2624' (P. cerasifera $\mathrm{x} P$. munsoniana $\mathrm{W}$. Wight \& Hedrick), compared to own-rooted scion tree (control, without rootstock).

The experimental design was in randomized blocks, with three replicates and one tree per plot. Nursery trees were produced in a commercial nursery, and rootstocks were multiplied by herbaceous cutting in intermittent mist system to ensure genetic fidelity.

The field trial was established on August 2014, at spacing of $5 \mathrm{~m} \times 2 \mathrm{~m}$, in a chemically corrected area according to soil analysis. The conduction system was "double Y", with the selection of a primary scaffold for each side of line and subsequent duplication, establishing four secondary scaffolds.

Trunk growth diameter in scion and rootstock was determined during the first three vegetative cycles after planting (2014/15, 2015/16 and 2016/17), at planting and at the end of each vegetative cycle (July), measured at $5 \mathrm{~cm}$ above and below the grafting point with a digital caliper. In own-rooted plants, measurements were made at the same height as grafted trees, having the beginning of budding on the original cutting as reference. The measurements of diameters was used to calculate the Periodic Increment $(\mathrm{IP})=\mathrm{Df}-\mathrm{Di}$, where Df is the final diameter at the $3^{\text {rd }}$ cycle (July / 2017) and Di the initial diameter (planting).

The peroxidase activity was determined in leaves in four samplings, two in the second vegetative cycle (January and March 2016), and two in the third vegetative cycle (October and December 2016). Samples consisted of six healthy mature leaves per tree, located in the middle third of scaffolds, on both sides of trees. Leaves were packed in polyethylene bags and kept in ice-cold styrofoam boxes while extraction was performed in laboratory, and extracts were frozen. The enzyme activity in the rootstock and scion trunk bark was determined in October of the $3^{\text {rd }}$ vegetative cycle, from collection of $0.25 \mathrm{~cm}^{2}$ bark $5 \mathrm{~cm}$ above and below the grafting point.

For the determination of peroxidase activity, the method of Allain et al. (1974) was used. The enzymatic extract of leaves was obtained by homogenization of 200 $\mathrm{mg}$ of fresh matter, macerated with $2 \mathrm{~mL}$ of potassium phosphate buffer, followed by centrifugation at $3,000 \mathrm{rpm}$ for 3 minutes at $4{ }^{\circ} \mathrm{C}$. The bark extract followed the same methodology; however, using $100 \mathrm{mg}$ of bark macerated with the aid of liquid nitrogen.

The reaction system contained $0.5 \mathrm{~mL}$ of enzyme extract; $0.5 \mathrm{~mL}$ potassium phosphate buffer $(0.2 \mathrm{M} \mathrm{pH} 6.7)$; $0.5 \mathrm{~mL} 30 \% \mathrm{H}_{2} \mathrm{O}_{2}$ solution; and $0.5 \mathrm{~mL}$ of dichlorophenol and aminoantipyrine solution (163 $\mathrm{mg}$ dichlorophenol $+81.3 \mathrm{mg}$ aminoantipyrine in $100 \mathrm{~mL} \mathrm{H}_{2} \mathrm{O}$ ). Tubes were incubated in a $30^{\circ} \mathrm{C}$ water bath for 3 minutes and the reaction was interrupted by the addition of $2 \mathrm{~mL}$ of absolute ethanol. After shaking, reading was performed in spectrophotometer at $505 \mathrm{~nm}$. Peroxidase activity was expressed in $\mu \mathrm{mol} \mathrm{H}_{2} \mathrm{O}_{2} / \mathrm{min} / \mathrm{mg}$ protein applying the equation: $\mathrm{U}=\mathrm{L} * \mathrm{VT}$, where $\mathrm{U}$ is the peroxidase activity unit; $\mathrm{L}$ is the absorbance reading, assuming value of 6.58; and VT the total reaction volume $(2 \mathrm{~mL})$. The $\mathrm{U}$ value was divided by the soluble protein content of the sample, obtaining the peroxidase activity in each minute of reaction per milligram of protein.

Protein content was determined by the method of Bradford (1976). The extract was the same used for peroxidase determination. For analysis, $0.1 \mathrm{~mL}$ of extract diluted in buffer solution was used to adjust readings, and $5.0 \mathrm{~mL}$ of Bradford reagent, followed by resting for five minutes. Readings were performed in spectrophotometer at $595 \mathrm{~nm}$ and calculated from the standard casein curve.

Data on leaf peroxidase activity, at each evaluation time, and periodic trunk increment, were submitted to analysis of variance. The peroxidase activity in the bark of rootstocks and scion was analyzed according to the $19 \times 2$ factorial scheme (treatments $\mathrm{x}$ sample collection position). Comparison of rootstock and scion diameters at planting and at the end of each cycle was performed in split-time plots (main plot $=$ rootstock; subplot $=$ evaluation times). Differences between means were compared by the ScottKnott test at 5\% error probability.

\section{Results and discussion}

During the first three vegetative cycles, all grafted trees onto 'Marianna 2624' (P. cerasifera $\mathrm{x}$ P. munsoniana) rootstock died, as well as $66.6 \%$ of trees grafted onto Clone 15 japanese apricot selection and 'Santa Rosa' plum, and 33.3\% of trees grafted onto Mexico F1, 'Barrier' (P. persica $\times$ P. davidiana) and 'Mirabolano 29C' $(P$. cerasifera), the latter for unidentified reasons. Most deaths occurred in the $1^{\text {st }}$ and $2^{\text {nd }}$ vegetative cycles after planting, and at the end of the $3^{\text {rd }}$ cycle, after leaf fall, the death of the last trees grafted onto 'Marianna 2624' and 'Santa Rosa' rootstocks was verified.

Graft incompatible situations between rootstock and scion are more common when genetic materials from different species or interspecific hybrids are used, as verified here. However, stating that the only reason for mortality is graft incompatibility is not appropriate, as other factors related to climatic conditions, crop management, nursery tree quality, pests, among others, can lead to plant death, which is not always possible to identify.

Most dead trees had previous lower growth, shriveling and red leaf spots, evolving to early leaf fall, as observed by Telles et al. (2009), Comiotto et al. (2012) and Pereira et al. (2015) in grafted peach cultivars on Japanese 
apricot seedlings as rootstocks. Neves et al. (2017) and Varago (2017) verified the effective graft incompatibility of peach onto 'Mirabolano 29C' and 'Marianna 2624'. At this trial, with exceptionof just one dead tree, 'Mirabolano 29C'as a rootstock did not reveal clear graft symptoms of incompatibility with 'Barbosa' peach at first three years.

Symptoms characterize translocated incompatibility, reducing the rate of root growth and carbohydrate translocation in the connection region, with accumulation in the scion cultivar, due to weak union or rupture of cambium and vascular system among grafted parts (ZARROUK et al., 2010). Callus formation occurs in compatible and incompatible combinations, but cambium formation seems to slow down in grafts combinations between different species in relation to intraspecific grafts, showing that the final rejection is predetermined in the early stages of graft formation (PINA et al. al., 2012).

The causes of sap translocation blockage are not completely understood, but could be caused by cambial tissue necrosis or lack of vascular tissue differentiation, with fewer phloem cells and elements in the graft area, which may cause rupture (PINA; ERREA, 2009; MARTÍNEZ-BALLESTA et al., 2010). Degeneration of rootstock tissues may occur by the accumulation of toxic compounds such as cyanide, derived from the hydrolysis of cyanogenic glycosides in the connection of parts, preventing vascular connections (NOCITO et al., 2010).

Another possibility of graft incompatibility between Prunus species is the vascular discontinuity and phloem degeneration in the connection area due to the occurrence of non-functional plasmodesmas responsible for cell connection (PINA; ERREA, 2005; PINA; ERREA, 2009; PINA et al., 2009), impairing the transport of photoassimilates. Also involving the discontinuity of the vascular system, Pereira et al. (2018) verified incompatibility of 'Chimarrita' and 'Maciel' peaches grafted onto Japanese apricot propagated by seeds when finding higher prunasin concentration and phenylalanine amonialylase (PAL) activity in the rootstock, and higher concentration of total phenolic compounds and antioxidant activity in graft and rootstock.

The determination of the peroxidase activity was performed to detect any evidence related to the existence of graft incompatibility between scion and rootstock. The results showed that the peroxidase activity in scion leaves on January of the $2^{\text {nd }}$ vegetative cycle and October and December of the $3^{\text {rd }}$ vegetative cycle, did not differ by the rootstock effect and in relation to the own-rooted scion tree (Table 1), periods of mild temperature and higher vegetative growth. However, it is observed on March of the $2^{\text {nd }}$ cycle, with trees still leafy but already showing growth reduction, with declining temperature, leading to the beginning of dormancy, in which for several combinations, greater peroxidase activity in relation to other seasons was found, especially compared to January.
The highest peroxidase activity was found in leaves of scion grafted onto 'Flordaguard' hybrid, followed by those grafts on Clone 15 and 'Rigitano', and 'Santa Rosa', the 'Ishtara' and 'Cadaman' hybrids, and Mexico F1 and I-6752-4 peach selections, with values higher than the ownrooted scion, therefore, in most interspecific combinations.

Analyzing the rootstock trunk bark, the highest peroxidase activity was verified in 'Genovesa', followed by 'Tsukuba-3', 'Capdeboscq', 'Ishtara', 'Santa Rosa' and Mexico F1, in relation to the own-rooted scion (Table 1). 'Tsukuba-1' trunk bark also showed higher enzyme activity compared to the scion bark. In the other combinations, the peroxidase activity in the rootstock and scion did not differ. Peroxidase activity on scion bark was not affected by rootstock, corroborating results obtained for leaves at the same season (October) (Table 1).

The highest peroxidase activity observed in early autumn leaves, in most combinations, may be justified by the fact that catalases and peroxidases increase in the early stages of cold acclimatization involved in the removal of $\mathrm{H}_{2} \mathrm{O}_{2}$ produced during the reactions of synthesis of proteins, organelles and ATP (MARAFON et al., 2009), and also because peroxidase can be regulated by day length, which is shorter in colder seasons (FERNÁNDEZPÉREZ et al., 2015). Higher peroxidase activity was observed in the trunk bark during dormancy, influencing metabolic reactions and physiological processes in plant tissues (MARAFON et al., 2009; TELLES et al., 2009; ZARROUK et al., 2010). Therefore, elevation detected in leaves at the end of the vegetative cycle indicates changes in peroxidase activity also in the trunk of graft combinations analyzed.

The higher peroxidase activity detected in the rootstock bark in relation to the scion bark, for several combinations (Table 1), can be attributed to the differences in the degree of lignification of tissues of both parts, considering that this enzyme acts on lignin biosynthesis (PASSARDI et al., 2005; NOCITO et al., 2010; ZARROUK et al., 2010; LIU, 2012; PINA et al., 2012; PEREIRA et al., 2013; FERNÁNDEZ-PÉREZ et al., 2015 BARON et al., 2018). Plant lignification is a complex cellular process that occurs in three sequential steps: synthesis of monolignols in the cytosol; transport of monomeric precursors across the plasma membrane; and oxidative polymerization of monolignols to form lignin macromolecules within the cell wall (LIU, 2012).

Significant difference was found between peroxidase activity in the scion bark and 'Santa Rosa' rootstock (Table 1), which may indicate graft incompatibility, causing the death of all plants, although other combinations showed even larger differences, with no visible symptoms of incompatibility. However, japanese plum nursery trees are commercially produced by grafting onto peach rootstocks, suggesting that inversion of rootstock and scion position may influence the success of graft combination. Telles 
et al. (2009) reported that small variations in peroxidase activity between rootstock and scion suggests that the materials are compatible and have similar lignin production, but changes in environmental conditions, attack of infectious agents and mechanical injuries induce and / or modify peroxidase activity as a way to increase the plant's defense capacity.

Table 1. Peroxidase activity in the leaves and bark of 'Barbosa' peach grafted onto eighteen clonal rootstocks and own-rooted trees. Passo Fundo, RS

\begin{tabular}{|c|c|c|c|c|c|c|}
\hline \multirow{4}{*}{ Treatments } & \multicolumn{6}{|c|}{$\begin{array}{c}\text { Peroxidase activity } \\
\left(\mu \mathrm{mol} \mathrm{H}_{2} \mathrm{O}_{2} \text { decomposed per min / mg protein) }\right.\end{array}$} \\
\hline & \multicolumn{4}{|c|}{ Leaves } & \multirow{2}{*}{\multicolumn{2}{|c|}{$\begin{array}{c}\text { Bark } \\
3^{\text {rd }} \text { vegetative cycle } \\
(10 / 2016)\end{array}$}} \\
\hline & \multicolumn{2}{|c|}{$2^{\text {nd }}$ vegetative cycle } & \multicolumn{2}{|c|}{$3^{\text {rd }}$ vegetative cycle } & & \\
\hline & $01 / 2016$ & $03 / 2016$ & $10 / 2016$ & $12 / 2016$ & Rootstock & Scion \\
\hline Own-rooted trees & $8.7^{\mathrm{ns}}$ & $11.4 \mathrm{c}$ & $14.5^{\mathrm{ns}}$ & $13.7^{\mathrm{ns}}$ & $5.4 \mathrm{Ac}^{*}$ & $4,7 \mathrm{Aa}^{*}$ \\
\hline Flordaguard & 10.2 & $39.7 \mathrm{a}$ & 10.9 & 13.7 & 4.8 Ac & $5,2 \mathrm{Aa}$ \\
\hline I-67-52-4 & 9.1 & $24.9 \mathrm{~b}$ & 12.3 & 14.4 & 4.6 Ac & $6,1 \mathrm{Aa}$ \\
\hline Clone 15 & 11.3 & $21.3 \mathrm{~b}$ & 10.2 & - & $6.1 \mathrm{Ac}$ & $6,1 \mathrm{Aa}$ \\
\hline Santa Rosa & 8.6 & $21.1 \mathrm{~b}$ & 13.2 & 10.2 & $7.3 \mathrm{Ab}$ & $3,7 \mathrm{Ba}$ \\
\hline Ishtara & 9.1 & $20.3 \mathrm{~b}$ & 12.6 & 14.5 & $7.7 \mathrm{Ab}$ & $3,7 \mathrm{Ba}$ \\
\hline Cadaman & 11.5 & $18.3 \mathrm{~b}$ & 11.7 & 12.4 & 4.4 Ac & $4,8 \mathrm{Aa}$ \\
\hline México F1 & 9.2 & $17.1 \mathrm{~b}$ & 10.2 & 11.0 & $7.2 \mathrm{Ab}$ & $4,9 \mathrm{Ba}$ \\
\hline Rigitano & 8.7 & $16.5 \mathrm{~b}$ & 15.6 & 15.9 & 4.7 Ac & $5,2 \mathrm{Aa}$ \\
\hline Genovesa & 9.3 & $15.4 \mathrm{c}$ & 13.1 & 12.6 & $11.8 \mathrm{Aa}$ & $5,2 \mathrm{Ba}$ \\
\hline Mirabolano 29C & 8.9 & $14.7 \mathrm{c}$ & 14.6 & 10.2 & $6.6 \mathrm{Ac}$ & $6,5 \mathrm{Aa}$ \\
\hline G x N.9 & 8.6 & $12.4 \mathrm{c}$ & 14.2 & 11.8 & 5.6 Ac & 4,3 Aa \\
\hline Tsukuba-1 & 10.4 & $11.9 \mathrm{c}$ & 9.3 & 11.2 & $6.8 \mathrm{Ac}$ & $4,3 \mathrm{Ba}$ \\
\hline Barrier & 10.2 & $11.9 \mathrm{c}$ & 11.6 & 10.9 & 4.8 Ac & $4,5 \mathrm{Aa}$ \\
\hline Capdeboscq & 8.7 & $10.6 \mathrm{c}$ & 9.7 & 10.7 & 7.9 Ab & $4,4 \mathrm{Ba}$ \\
\hline Tsukuba-2 & 9.1 & $10.3 \mathrm{c}$ & 12.2 & 13.0 & 4.8 Ac & $3,7 \mathrm{Aa}$ \\
\hline Tsukuba-3 & 10.6 & $9.6 \mathrm{c}$ & 12.3 & 13.2 & $8.8 \mathrm{Ab}$ & $4,0 \mathrm{Ba}$ \\
\hline Okinawa & 9.7 & $8.9 \mathrm{c}$ & 12.5 & 11.9 & $5.6 \mathrm{Ac}$ & $5,8 \mathrm{Aa}$ \\
\hline Marianna 2624 & 8.0 & - & - & - & - & - \\
\hline Mean & 9.5 & 16.5 & 12.3 & 12.6 & 6.4 & 4,8 \\
\hline C.V. $(\%)$ & 12.8 & 31.74 & 25.21 & 16.46 & & \\
\hline
\end{tabular}

Means followed by the same uppercase letter in the row and lowercase in the column do not differ by the Scott-Knott test at $5 \%$ error probability. ${ }^{\text {ns }}$ not significant by test F. (-) Dead plants. * In own-rooted plants, measurements were made at the same height as grafted trees, having the beginning of budding on the original cutting as reference.

Incompatibility may be related to quantitative and / or qualitative differences in phenol content involved in cell differentiation and tissue lignification, leading to alterations in the activity of enzymes that regulate the synthesis of these compounds (PINA; ERREA, 2008; TELLES et al., 2009; NOCITO et al., 2010; ZARROUK et al., 2010; PINA et al., 2012; PEREIRA et al., 2013). Increased peroxidase activity between incompatible grafted trees has been observed as a result of the accumulation of phenols at the grafting point, causing disturbances in vascular connections (ZARROUK et al., 2010; HUDINA et al., 2014).
A less efficient antioxidant system would be present in incompatible combinations, or the production of inappropriate cell types, or the production of reactive oxygen species (ROS), such as hydrogen peroxide, not allowing proper grafting union (IRISARRI et al., 2015). The accumulation of different proteins has been shown to be associated with various events in the grafting union, such as elimination of excess wound-induced reactive oxygen species, ethylene biosynthesis at the grafting interface, and in callus proliferation by promoting protein synthesis and in the differentiation of tracheal elements (MO et al., 2017). 
For rootstock and scion diameter growth evaluations, data for rootstocks that presented $66 \%$ or more of dead plants, i.e., 'Marianna 2624', Clone 15 and 'Santa Rosa' were excluded. The diameter of all rootstocks and own-rooted scion trees increased significantly in the three cycles evaluated (Table 2). In the first vegetative cycle, no significant differences were verified between rootstocks and own-rooted scion trees. At the end of the $2^{\text {nd }}$ cycle, 'Okinawa', 'Flordaguard', Mexico F1, 'Mirabolano 29C', 'Tsukuba-2', 'Tsukuba-3' and ownrooted rootstocks presented larger diameter. At the end of the three cycles, in addition to the six rootstocks above, own-rooted trees, 'Tsukuba-1', 'Capdeboscq' and 'Cadaman' rootstocks also joined the larger diameter group. Smaller diameter rootstocks were I-67-52-4, G x N.9, 'Rigitano', 'Genovesa', 'Barrier' and 'Ishtara'.

Table 2. Trunk diameter of fifteen clonal rootstocks grafted with 'Barbosa' peach tree and own-rooted trees at planting and at the end of the first three vegetative cycles, and Periodic Increment of the trunk diameter (35 months). Passo Fundo, RS

\begin{tabular}{|c|c|c|c|c|c|}
\hline \multirow[b]{3}{*}{ Treatments } & \multicolumn{4}{|c|}{ Trunk diameter - rootstock $(\mathrm{mm})$} & \multirow{3}{*}{$\begin{array}{l}\text { Periodic Incremen } \\
\qquad \mathrm{IP}=\left(\mathrm{Df}^{(3)}-\mathrm{Di}^{(4)}\right) \\
(\mathrm{mm})\end{array}$} \\
\hline & \multicolumn{4}{|c|}{ Days after planting } & \\
\hline & $\begin{array}{c}\text { Planting } \\
\text { (sep/2014) }\end{array}$ & $\begin{array}{c}1^{\text {st }} \text { cycle } \\
(280 \text { days })\end{array}$ & $\begin{array}{c}2^{\text {nd }} \text { cycle } \\
(640 \text { days })\end{array}$ & $\begin{array}{c}3^{\text {rd }} \text { cycle } \\
(800 \text { days })\end{array}$ & \\
\hline Own-rooted trees & $10.6 \mathrm{Da}^{*}$ & $31.1 \mathrm{Ca}^{*}$ & $49.0 \mathrm{Ba}^{*}$ & $67.0 \mathrm{Aa}^{*}$ & $56.3 \mathrm{a}^{*}$ \\
\hline Okinawa & 7.8 Da & $28.2 \mathrm{Ca}$ & $50.4 \mathrm{Ba}$ & $72.3 \mathrm{Aa}$ & $64.5 \mathrm{a}$ \\
\hline Flordaguard & 7.1 Da & $24.1 \mathrm{Ca}$ & $47.9 \mathrm{Ba}$ & $71.5 \mathrm{Aa}$ & $64.4 \mathrm{a}$ \\
\hline Tsukuba-2 & 7.2 Da & $19.2 \mathrm{Ca}$ & $44.1 \mathrm{Ba}$ & $68.4 \mathrm{Aa}$ & $61.2 \mathrm{a}$ \\
\hline Tsukuba-1 & 6.7 Da & $22.1 \mathrm{Ca}$ & $38.4 \mathrm{Bb}$ & $66.0 \mathrm{Aa}$ & $59.2 \mathrm{a}$ \\
\hline Capdeboscq & 7.1 Da & $24.6 \mathrm{Ca}$ & $38.6 \mathrm{Bb}$ & $64.2 \mathrm{Aa}$ & $57.1 \mathrm{a}$ \\
\hline Tsukuba-3 & 8.1 Da & $22.0 \mathrm{Ca}$ & $41.5 \mathrm{Ba}$ & $63.9 \mathrm{Aa}$ & $55.8 \mathrm{a}$ \\
\hline México F1 & 8.7 Da & $27.5 \mathrm{Ca}$ & $45.8 \mathrm{Ba}$ & $62.6 \mathrm{Aa}$ & $53.9 \mathrm{a}$ \\
\hline Mirabolano 29C & $9.8 \mathrm{Da}$ & $32.9 \mathrm{Ca}$ & $44.8 \mathrm{Ba}$ & $60.1 \mathrm{Aa}$ & $50.2 \mathrm{a}$ \\
\hline Cadaman & 7.7 Ca & $19.9 \mathrm{Ca}$ & $39.7 \mathrm{Bb}$ & $59.9 \mathrm{Aa}$ & $52.2 \mathrm{a}$ \\
\hline I-67-52-4 & $5.9 \mathrm{Da}$ & $22.8 \mathrm{Ca}$ & $35.0 \mathrm{Bb}$ & $53.2 \mathrm{Ab}$ & $47.3 \mathrm{~b}$ \\
\hline Genovesa & $9.0 \mathrm{Da}$ & $25.2 \mathrm{Ca}$ & $37.7 \mathrm{Bb}$ & $49.0 \mathrm{Ab}$ & $39.9 \mathrm{~b}$ \\
\hline G x N.9 & $8.8 \mathrm{Ca}$ & $17.3 \mathrm{Ca}$ & $26.0 \mathrm{Bb}$ & $47.0 \mathrm{Ab}$ & $38.2 \mathrm{~b}$ \\
\hline Rigitano & 7.6 Da & $23.8 \mathrm{Ca}$ & $33.5 \mathrm{Bb}$ & $46.8 \mathrm{Ab}$ & $39.2 \mathrm{~b}$ \\
\hline Barrier & 8.5 Da & $22.3 \mathrm{Ca}$ & $35.2 \mathrm{Bb}$ & $44.9 \mathrm{Ab}$ & $36.4 \mathrm{~b}$ \\
\hline Ishtara & 7.5 Da & $18.7 \mathrm{Ca}$ & $30.5 \mathrm{Bb}$ & $42.2 \mathrm{Ab}$ & $34.7 \mathrm{~b}$ \\
\hline Mean & 8.0 & 23.9 & 39.9 & 58.7 & 50.7 \\
\hline C.V. PP $(\%)^{(1)}$ & 31.3 & & & & \\
\hline C.V. SP $(\%)^{(2)}$ & 17.1 & & & & \\
\hline C.V. $(\%)$ & & & & & 21.84 \\
\hline
\end{tabular}

Means followed by the same uppercase letter in the row and lowercase in the column do not differ by the Scott-Knott test at $5 \%$ error probability. (1) Main plot (rootstock); (2) Subplot (evaluation times) (3) Df - final diameter; (4) Di - Initial diameter. * In own-rooted plants, measurements were made at the same height as grafted trees, having the beginning of budding on the original cutting as reference.

Scion trunck diameter, completed in the $1^{\text {st }}$ cycle, was higher in plants grafted onto 'Okinawa', 'Flordaguard', Mexico F1, 'Tsukuba-1', 'Tsukuba-3', 'Capdeboscq', 'Rigitano', 'Mirabolano 29C' and 'Genovesa' rootstocks, not differing from own-rooted trees (Table 3 ). In the $2^{\text {nd }}$ cycle, larger diameter grafts were verified on 'Okinawa', 'Tsukuba-2', 'Flordaguard', Mexico F1, 'Tsukuba-1', 'Tsukuba-3', 'Rigitano' and 'Mirabolano 29C' rootstocks, not differing from ownrooted trees, remaining with larger diameter at the end of the $3^{\text {rd }}$ cycle, except for scion onto 'Tsukuba-3', 'Rigitano' and 'Mirabolano 29C' rootstocks. 
Table 3. Trunk diameter of 'Barbosa' peach tree grafted on fifteen rootstock, and own-rooted scion trees at planting and at the end of the first three vegetative cycles (July) and Periodic Increment (35 months). Passo Fundo, RS

\begin{tabular}{|c|c|c|c|c|c|}
\hline \multirow[b]{3}{*}{ Treatments } & \multicolumn{4}{|c|}{ Trunk diameter - scion (mm) } & \multirow{3}{*}{$\begin{array}{l}\text { Periodic Increment } \\
\mathrm{IP}=\left(\mathrm{Df}^{(3)}-\mathrm{Di}^{(4)}\right) \\
(\mathrm{mm})\end{array}$} \\
\hline & \multicolumn{4}{|c|}{ Days after planting } & \\
\hline & $\begin{array}{c}\text { Planting } \\
\text { (sep/2014) }\end{array}$ & $\begin{array}{c}1^{\text {st }} \text { cycle } \\
(280 \text { days })\end{array}$ & $\begin{array}{l}2^{\text {nd }} \text { cycle } \\
(640 \text { days })\end{array}$ & $\begin{array}{c}3^{\text {rd }} \text { cycle } \\
(800 \text { days })\end{array}$ & \\
\hline Own-rooted trees & $7.3 \mathrm{Da}^{*}$ & $26.8 \mathrm{Ca}^{*}$ & $45.5 \mathrm{Ba}^{*}$ & $60.2 \mathrm{Aa}^{*}$ & $52.9 \mathrm{a}^{*}$ \\
\hline Okinawa & 4.5 Da & $26.9 \mathrm{Ca}$ & $49.0 \mathrm{Ba}$ & $66.6 \mathrm{Aa}$ & $62.1 \mathrm{a}$ \\
\hline Tsukuba-2 & $5.6 \mathrm{Da}$ & $17.6 \mathrm{Cb}$ & $43.7 \mathrm{Ba}$ & $65.0 \mathrm{Aa}$ & $59.5 \mathrm{a}$ \\
\hline Flordaguard & $5.3 \mathrm{Da}$ & $22.6 \mathrm{Ca}$ & $44.0 \mathrm{Ba}$ & $63.4 \mathrm{Aa}$ & $58.2 \mathrm{a}$ \\
\hline México F1 & 8.2 Da & $25.6 \mathrm{Ca}$ & $43.4 \mathrm{Ba}$ & $61.9 \mathrm{Aa}$ & $53.7 \mathrm{a}$ \\
\hline Tsukuba-1 & 4.9 Da & $21.8 \mathrm{Ca}$ & $38.2 \mathrm{Ba}$ & $59.5 \mathrm{Aa}$ & $54.6 \mathrm{a}$ \\
\hline Capdeboscq & $4.8 \mathrm{Da}$ & $23.2 \mathrm{Ca}$ & $36.5 \mathrm{Bb}$ & $54.5 \mathrm{Ab}$ & $49.8 \mathrm{a}$ \\
\hline Tsukuba-3 & $5.7 \mathrm{Da}$ & $21.1 \mathrm{Ca}$ & $38.3 \mathrm{Ba}$ & $54.4 \mathrm{Ab}$ & $48.7 \mathrm{a}$ \\
\hline Rigitano & 4.2 Da & $25.0 \mathrm{Ca}$ & $40.7 \mathrm{Ba}$ & $54.1 \mathrm{Ab}$ & $49.9 \mathrm{a}$ \\
\hline Cadaman & 3.9 Da & $15.2 \mathrm{Cb}$ & $35.2 \mathrm{Bb}$ & $52.8 \mathrm{Ab}$ & $48.9 \mathrm{a}$ \\
\hline Mirabolano 29C & 7.8 Da & $27.0 \mathrm{Ca}$ & $41.1 \mathrm{Ba}$ & $52.0 \mathrm{Ab}$ & $44.2 \mathrm{~b}$ \\
\hline $\mathrm{I}-67-52-4$ & 4.2 Da & $17.4 \mathrm{Cb}$ & $33.2 \mathrm{Bb}$ & $50.0 \mathrm{Ab}$ & $45.9 \mathrm{~b}$ \\
\hline Genovesa & 5.7 Da & $21.2 \mathrm{Ca}$ & $35.2 \mathrm{Bb}$ & $47.2 \mathrm{Ac}$ & $41.5 \mathrm{~b}$ \\
\hline Ishtara & 4.9 Da & $18.3 \mathrm{Cb}$ & $28.7 \mathrm{Bc}$ & $40.2 \mathrm{Ad}$ & $35.3 \mathrm{~b}$ \\
\hline Barrier & $6.3 \mathrm{Da}$ & $19.6 \mathrm{Cb}$ & $29.5 \mathrm{Bc}$ & $39.4 \mathrm{Ad}$ & $35.9 \mathrm{~b}$ \\
\hline G x N.9 & $5.2 \mathrm{Ca}$ & $15.6 \mathrm{Bb}$ & $22.5 \mathrm{Bc}$ & $38.1 \mathrm{Ad}$ & $32.9 \mathrm{~b}$ \\
\hline Mean & 5.5 & 21.5 & 37.8 & 53.7 & 48.4 \\
\hline C.V. PP (\%) ${ }^{(1)}$ & 32.1 & & & & \\
\hline C.V. SP (\%) ${ }^{(2)}$ & 16.6 & & & & \\
\hline C.V. $(\%)$ & & & & & 19.99 \\
\hline
\end{tabular}

Means followed by the same uppercase letter in the row and lowercase in the column do not differ by the Scott-Knott test at $5 \%$ error probability. (1) Main plot (rootstock); (2) Subplot (evaluation times) (3) Df - final diameter; (4) Di - Initial diameter. * In own-rooted plants, measurements were made at the same height as grafted trees, having the beginning of budding on the original cutting as reference.

The combinations that presented, after three vegetative cycles, simultaneously the largest Periodic Increment (IP) of the trunck diameter at rootstock and scion (Tables 2 and 3) were grafted trees onto 'Okinawa", 'Tsukuba-1', 'Tsukuba- 2', 'Tsukuba-3', 'Flordaguard', Mexico F1, 'Capdeboscq' and 'Cadaman' rootstocks, without difference from own-rooted trees. Trees with lower rootstock-scion growth were grafted onto 'Ishtara', 'Barrier', 'GxN.9', 'Genovesa' and I-67-52-4 rootstocks.

Trees grafted onto 'Mirabolano 29C' showed higher rootstock IP, but graft growth remained in the lowest group. In turn, the trunck diameter of the 'Rigitano' rootstock presented lower IP, but the scion trunck diameter was positioned in the group with the largest increment.

In trees grafted onto 'Rigitano' rootstock, the trunk diameter showed excessive difference between rootstock and scion, with greater thickening at the grafting point. Similar symptoms have been verified by other authors (PEREIRA; MAYER, 2005; COMIOTTO et al., 2012; GALARÇA et al., 2013; PEREIRA et al., 2015; VARAGO,
2017), impairing productivity (GALARÇA et al., 2013), which is a fact attributed to a certain degree of graft incompatibility (COMIOTTO et al., 2012; PEREIRA et al., 2015) related to the botanical difference between $P$. persica and P. mume. Graft point hypertrophy may occur due to different growth rates between scion and rootstock, xylem and phloem formation. These differences in gene expression are associated with the accumulation of lignin, cellulose and callose in callus cells at the grafting union (MORENO et al., 2014).

Studies have shown the effect of different rootstocks on peach tree scion growth, generally in agreement with the results obtained. Higher trunk growth of 'Maciel' was verified when grafted onto 'Okinawa'or 'Nemaguard'; and 'Chimarrita' onto 'Nemaguard'or 'Flordaguard' (COMIOTTO et al., 2013). 'Okinawa', 'Flordaguard', Mexico F1' and G x N.9 rootstocks induced greater vigor to 'BRS Kampai' peach, not differing from ownrooted trees. Low scion vigor was provided by 'Marianna 2624', 'Mirabolano 29C', 'Genovesa', 'Santa Rosa' and 
'Ishtara', all plum rootstocks (VARAGO, 2017). The trunk diameter of 'Chimarrita' peach tree was most influenced by 'Capdeboscq', 'Okinawa' and 'Tsukuba 1' rootstocks (PICOLOTTO et al., 2009).

The results obtained from trunk growth are determined by several combined factors established by the rootstock and scion relationship, such as rootstock vigor, involving morphophysiological characteristics such as length and volume of the root system; quantitative and qualitative capacity of soil nutrient absorption, regulation of nutrient translocation, photoassimilates and growth hormones at the grafting point (MARCON FILHO et al., 2009; ZARROUK et al., 2010; PASA et al., 2011), which may involve different degrees of incompatibility for many reasons; and the age difference between rootstock and scion, in the case of young plants, such as those used in this study. In cases where there was vigor reduction, this fact can be considered positive when it favors fruit production, recognized as dwarfing effect (MARTÍNEZBALLESTA et al., 2010; TOMBESI et al., 2011), requiring longer evaluation period for conclusions.

Regarding the satisfactory performance of ownrooted trees, the justification lies precisely in the absence of the grafting point and some degree of graft incompatibility between parts that could negatively influence growth. The feasibility of using cuttings in the production of nursery trees of peach shows dependence on the formation of satisfactory fasciculate root system; adaptation to the soil and climatic conditions; presence or absence of diseases and pests; and evaluations of plant longevity, fruit quality and yield.

The results have shown that rootstocks can have different influence on plant vigor, allowing inferring that the indication of the best rootstock may depend on which scion cultivar will be grafted. Regarding peroxidase activity, although it may be a biochemical indicator of stress, the results reinforce the perception that it should not be used and generalized for the rapid characterization of incompatibility. Herrero et al. (2014) reported that, although of great importance, high peroxidase activity cannot be considered as a definitive early diagnosis of incompatibility, since it seems to be more related to cell wall lignification rather than to tissue degradation. Therefore, the role played by peroxidases in lignification does not generally allow justifying the reason for graft incompatibility and should be proposed with caution (BARON et al., 2018).

\section{Conclusions}

'Marianna 2624', Clone 15 and 'Santa Rosa' rootstocks show symptoms of graft incompatibility with 'Barbosa' peach, and grafting is not recommended.

Peroxidase activity differs by rootstock effect at the beginning of dormancy, and is higher than in vegetative growth, especially in interspecific combinations.

Peroxidase activity is a biochemical indicator of stress, but should not be used alone and generalized for rapid characterization of graft incompatibility.

The largest trunk diameter growth of rootstock and scion simultaneously is obtained in plants grafted onto 'Okinawa', 'Tsukuba-1', 'Tsukuba-2', Mexico F1 and 'Flordaguard' rootstocks, without differing from ownrooted 'Barbosa' trees (control).

\section{Acknowledgments}

The authors would like to thank Embrapa Clima Temperado (Pelotas-RS) for funding and the opportunity to be part of the "Development of Prunus spp. rootstocks for peaches, nectarines and plums" Research Project ( $\mathrm{N}^{\circ}$. 02.13.06.001.00.00).

\section{References}

ALlAIN, C.C.; POON, L.C.; CHEN, C.S.G.; RICHMOND, W.; FU, P.C. Enzimatic determination of total serum cholesterol. Clinical Chemistry, Washington, v.20, n.4, p.470-475, 1974.

BARON, D.; AMARO, A.C.E.; MACEDO, A.C.; DALANHOL, J.; BOARO, C.S.F.; FERREIRA, G. Grafting relations in atemoya ('Annona' $\mathrm{x}$ 'atemoya' Mabb.) plants: peroxidase and phenolic compounds. Australian Journal of Crop Science, Lismore, v. 12, n.9, p.1447, 2018.

BRADFORD, M.M.A. Rapid and sensitive method for the quantitation of microgram quantities of protein utilizing the principle of protein-dye binding. Analytical Biochemistry, Amsterdam, v.72, p.248, 1976.

COMIOTTO, A.; FACHINELLO, J.C.; HOFFMANN, A.; GALARÇA, S.P.; MACHADO, N.P.; PREZOTTO, M.E.; HASS, L.B. Desenvolvimento, produção e qualidade dos frutos de pessegueiros enxertados sobre diferentes portaenxertos. Sêmina: Ciências Agrárias, Londrina, v.34, n.6, p.3553-3562, 2013. 
COMIOTTO, A.; FACHINELLO, J.C.; HOFFMANN, A.; MACHADO, N.P.; GALARÇA, S.P.; BETEMPS, D.L. Vigor, floração, produção e qualidade de pêssegos 'Chimarrita' e 'Maciel' em função de diferentes portaenxertos. Ciência Rural, Santa Maria, v.42, n.5, p.788$794,2012$.

EMBRAPA. Centro Nacional de Pesquisa de Trigo. Laboratório de Agrometeorologia. Normais climatológicas (1961-1990): Passo Fundo. Disponível em: http://www.cnpt.embrapa.br/pesquisa/agromet/app/ principal/normais.php. Acesso em: 10 jan. 2017.

FERNÁNDEZ-PÉREZ, F.; VIVAR, T.; POMAR, F.; PEDREÑO, M.A.; NOVO-UZAL, E. Peroxidase 4 is involved in syringyl lignin formation in Arabidopsis thaliana. Journal of Plant Physiology, Amsterdam, v.175, p. 86-94, 2015.

GALARCA, S.P.; FACHINELLO, J.C.; BETEMPS, D.L.; HOFFMANN, A.; MARODIN, G.A.B.; PRETTO, A.; NUNES, F.S.; DIAS, F.P. Crescimento e desenvolvimento de pessegueiros 'Chirmarrita' and 'Maciel' sobre deferentes porta-enxertos e locais de cultivo. Ciência Rural, Santa Maria, v.43, n.2, p.219-224, 2013.

HARTMANN, H.T., KESTER, D.E.; DAVIES JR, F.T.; GENEVE, R. Plant propagation: principles and practices. New Jersey: Prentice Hall, 2011. 915p.

HERRERO, J.; CARRASCO, A.E.; ZAPATA, J.M. Arabidopsis thaliana peroxidases involved in lignin biosynthesis: in silico promoter analysis and hormonal regulation. Plant Physiology and Biochemistry, Paris, v.80, p.192-202, 2014.

HUDINA, M.; ORAZEM, P.; JAKOPIC, J.; STAMPAR, F. The phenolic content and its involvement in the graft incompatibility process of various pear rootstocks (Pyrus communis L.). Journal of Plant Physiology, Amsterdam, v.171, n.5, p.76-84, 2014.

IRISARRI, P.; BINCZYCKI, P.; ERREA, P.; MARTENS, H.J.; PINA, A. Oxidative stress associated with rootstockscion interactions in pear/quince combinations during early stages of graft development. Journal of Plant Physiology, Amsterdam, v.176, p.25-35, 2015.

LIU, C-J. Deciphering the enigma of lignification: precursor transport, oxidation, and the topochemistry of lignin assembly. Molecular Plant, Oxford, v.5, n.5, p.304-317, 2012.
MARAFON, A.C.; HERTER, F.G.; BACARIN, M.A.; HAWERROTH, F.J. Atividade da peroxidase durante o período hibernal de plantas de pessegueiro (Prunus persica (L.) Batsch) cv. Jubileu com e sem sintomas da morte-precoce. Revista Brasileira de Fruticultura, Jaboticabal, v.31, n.4, p.938-942, 2009.

MARCON FILHO, J.L.; RUFATO, L.; RUFATO, A. de R.; KRETZSCHMAR; A.A.; ZANCAN, C. Aspectos produtivos e vegetativos de macieiras cv. Imperial Gala interenxertadas com EM-9. Revista Brasileira de Fruticultura, Jaboticabal, v.31, n.3, p.784-791, 2009.

MARTÍNEZ-BALLESTA, M.C.; ALCARAZ-LOPES, C.; MURIEZ, B.; MOTA-CADENAS, C.; CARVAJAL, M. Physiological aspects of rootstock-scion interactions. Scientia Horticulturae, Amsterdam, v.127, n.2, p.112$118,2010$.

MAYER, N.A; UENO, B.A. Morte-precoce do pessegueiro e suas relações com porta-enxertos. Pelotas: Embrapa Clima Temperado, 2012. 42p.

MO, Z.; HE, H.; SU, W.; PENG, F. Analysis of differentially accumulated proteins associated with graft union formation in pecan (Carya illinoensis). Scientia Horticulturae, Amsterdam, v.224, p.126-134, 2017.

MORENO, M.A.; MOING, A.; LANSAC, M.; GAUDILLIERE, J.P.; SALESSES, G. Developments at the graft interface in homo- and hetero-graft. Plant Signaling and Behavior, Austin, v.9, p.e28852, 2014.

NEVES, T.R.; MAYER, N.A.; UENO, B. Graft incompatibility in Prunus spp. preceded by SPAD index reduction. Sêmina: Ciências Agrárias, Londrina, v.38, n.2, p.635-648, 2017.

NOCITO, F.F.; ESPEN, L.; FEDELI, C.; LANCILLI C.; MUSACCHI, L.; SERRA, S.; SANSAVINI, S.; COCUCCI, M.; SACCHI, G.A. Oxidative stress and senescence-like status of pear calli co-cultured on suspensions of incompatible quince microcalli. Tree Physiology, Victoria, v.30, p.450-458, 2010.

PASA, M. da S.; FACHINELLO, J.C.; SCHMITZ, J.D.; SOUZA, A.L.K. de; HERTER, F.G. Hábito de frutificação e produção de pereiras sobre diferentes porta-enxertos. Pesquisa Agropecuária Brasileira, Brasília, DF, v.46, n.9, p.998-1005, 2011.

PASSARDI, F.; COSIO, C.; PENEL, C.; DUNAND, C. Peroxidase have more functions than a Swiss army knife. Plant Cell Report, Geneva, v.24, p.255-265, 2005. 
PEREIRA, F.M.; MAYER, N.A. Pessegueiro: tecnologias para a produção de mudas. Jaboticabal: Funep, 2005. $65 p$.

PEREIRA, I. dos S.; FACHINELLO, J.C.F.; ANTUNES, L.E.C.; CAMPOS, Â.D.; PINA, A. Incompatibilidade de enxertia em Prunus. Ciência Rural, Santa Maria, v. 44, n. 9, P. 1519-1526, 2014.

PEREIRA, I. DOS S.; PINA, A.; ANTUNES, L.E.C.; CAMPOS, Â.D.; FACHINNELLO, J.C. Genotypic differences in cyanogenic glycosides levels of compatible Prunus persica P. persica and incompatible P. persica P. mume combinations. Bragantia, Campinas, v.77, n.1, p. 2018.

PEREIRA, I.S.; ANTUNES, L.E.C.; PICOLOTTO, L.; FACHINELLO, J.C. Incompatibilidade de enxertia induz aumento da suscetibilidade de cultivares de pessegueiro à Xanthomonas arboricola pv. Pruni. Ciência Rural, Santa Maria, v.45, p.1147-1153, 2015.

PEREIRA, I.S.; FACHINELLO, J.C.; ANTUNES, L.E.C.; ERREA, P.; MESSIAS, R.S.; PINA, A. Expression of the 4-coumarate:coa ligase gene family in compatible and incompatible prunus grafts. Acta Horticulturae, The Hague, v.976, p.333-338, 2013.

PICOLOTTO, L.; MANICA-BERTO, R.; PAZIN, D.; PASA, M. da S.; SCHMITZ, J.D.; PREZOTTO, M.E.; BETEMPS, D.; BIANCHI, V.J.; FACHINELLO, J.C. Características vegetativas, fenológicas e produtivas do pessegueiro cultivar Chimarrita enxertado em diferentes porta-enxertos. Pesquisa Agropecuária Brasileira, Brasília, DF, v.44, n.6, p.583-599, 2009.

PINA A.; ERREA, P.; SCHULZ, A.; MARTENS, H.J. Cell-to-cell transport through plasmodesmata in tree callus cultures. Tree Physiology, Victoria, v.29, p.809818, 2009.

PINA, A.; ERREA, P. Differential induction of phenylalanine ammonia-lyase gene expression in response to in vitro callus unions of Prunus spp. Journal of Plant Physiology, Amsterdam, v.165, p.705-714, 2008.
PINA, A.; ERREA, P. Morphological and histochemical features of compatible and incompatible stem unions. Acta Horticulturae, The Hague, v.814, p.453-456, 2009.

PINA, A.; ERREA, P.; MARTENS, H.J. Graft union formation and cell-to-cell communication via plasmodesmata in compatible and incompatible stem unions of Prunus spp. Scientia Horticulturae, Amsterdam, v.143, p.144-150, 2012.

PINA, A.; ERREA, P.A. A review of new advances in mechanism of graft compatibility-incompatibility. Scientia Horticulturae, Amsterdam, v.106, n.1, p.1-11, 2005.

TELLES, C.A.; BIASI, L.A.; MINDÊLLO NETO, U.R.; DESCHAMPS, C. Fenóis totais, peroxidase e suas relações com a compatibilidade de mudas de pessegueiro interenxertadas. Ciência e Agrotecnologia, Pelotas, v.33, p.86-91, 2009.

TOMBESI, S.;ALMEHDI,A.; DEJONG, T.M.Phenotyping vigour control capacity of new peach rootstocks by xylem vessel analysis. Scientia Horticulturae, Amsterdam, v.127, n.3, p.353-357, 2011.

USENIK, V.; FABCIC, J.; STAMPAR, F. Early detection of graft incompatibility in apricot (Prunus armeniaca L.) using phenol analyses. Scientia Horticulturae, Amsterdam, v.109, p.332-338, 2006.

VARAGO, A.L. Porta-enxertos clonais no crescimento, produtividade e qualidade de frutos de pessegueiro 'BRS Kampai'. 2017. Dissertação (Mestrado Agronomia) - Universidade Tecnológica Federal do Paraná, Pato Branco, 2017.

ZARROUK, O.; TESTILLANO, P.S.; RISUEÑO, M.C.; MORENO, M.Á.; GOGORCENA, Y. Changes in cell/ tissue organization and peroxidase activity as markers for early detection of graft incompatibility in peach/ plum combinations. Journal of the American Society for Horticultural Science, Mount Vernon, v.135, n.1, p.9-17, 2010. 